\title{
Role of sedimentation in continental rifting from comparing two narrow rift valleys the Salton Trough and Death Valley-California
}

\author{
Musa Hussein", Laura F. Serpa, Aaron A. Velasco, Diane Doser
}

Department of Geological Sciences, University of Texas at El Paso, El Paso, USA;

${ }^{*}$ Corresponding Author: mjhussein@utep.edu

Received 3 September 2011; revised 8 October 2011; accepted 19 October 2011.

\begin{abstract}
To unravel the forces and better understand the processes that drive continental rifting, and to understand the role of sedimentation in promoting the rifting process, we compare; the different geological features of two narrow rifts, the Salton Trough and Death Valley, California. According to our models, the Moho is $22 \mathrm{~km}$ deep to the southwest of the Salton Sea on US-Mexico border and it deepens to $30 \mathrm{~km}$ in the region west of the Salton Trough. In Death Valley, the Moho is $24 \mathrm{~km}$ deep in the central part of the basin and it deepens to $32 \mathrm{~km}$ outside of the basin. The dome shaped Moho in both rifts is suggested to be primarily the product of magmatic activity in the lower crust and upper mantle. Death Valley is narrow rift in the initial stage of rifting with several sedimentary basins $2-4$ km deep. In Death Valley magmatic (thermal) forces appears to drive the rifting process. The Salton Trough is wider than Death Valley and is moving toward sea floor spreading. The depth of the sedimentary basins ranges from $8-10 \mathrm{~km}$ and a combination of thermal and sedimentation appears to drive rifting processes in the Salton Trough.
\end{abstract}

Keywords: Crustal Models; Data Incorporation; Magmatic Underplating; Narrow Rifts

\section{INTRODUCTION}

Rifts have developed in continents at least since plate tectonic was established early in earth's history [1]. Active rifting is characterized by regional uplift of the crust and local development of normal faults and basins. Continued extension leads to seafloor spreading and freezes the transitional crust in place, so the relative significance of passive versus active rifting is preserved in deeply buried units [2].

Comparative studies of rifts are a useful way to organize what is known, recognize what is not known, and improve our understanding of the processes which led to continental rifting [3]. Magmatism resulting from such rifting can help refine our understanding of the strength of the lithosphere, the state of the underlying mantle and the transformation from rifting to sea floor spreading [4]. Many studies have highlighted the distinct differences between rifts and other styles of extensional provinces [5-10], and many experiments have been performed to address the connection of mantle flow to continental rifting [11,12]. The study of particular rift systems and comparisons between rift systems has shown distinct characteristics that imply fundamental differences in geologic formation processes [3].

Incorporation of gravity models, receiver function analysis, with previous seismic studies [13-15] provides additional constraints on the composition and structure of the crust and upper mantle. In particular, detailed subsurface modeling of multiple data sets can provide information on the driving forces of rifting, the structure and magmatic history, and the characteristics that determine whether and how a rift might evolve into the next stage as either an abandoned continental rift or an ocean basin.

In this paper, we combine receiver function and gravity data with pre-existing seismic models to illustrate the role of sedimentation rate and sediments flux in promoting the rifting process.

\section{TECTONIC SETTINGS}

The Salton Trough (Figure 1) is a modern example of the evolution from continental to oceanic crust due to rifting within a transtensional regime. The Salton Trough is characterized by high heat flow; young volcanism and the presence of several pull part basins [16]. It extends to 


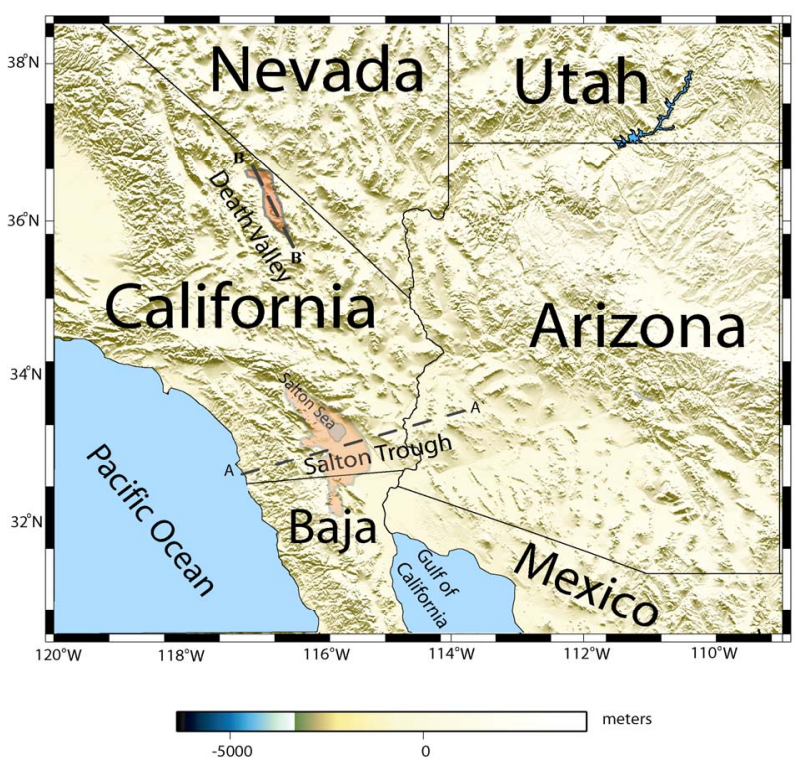

Figure 1. Location map showing the Salton Trough area and Death Valley area. Dashed line A-A' shows the location of the Salton Trough crustal model. Dashed line B-B' shows the location of Death Valley crustal model.

the northwest from the Gulf of California for a distance of $250 \mathrm{~km}$.

The Salton Trough contains about $10 \mathrm{~km}$ of sediments deposited as alluvial debris, thin marine beds, and deposits from the ancestral Colorado River [17]. The present day Salton Trough differs from analogous structures to the south in the Gulf of California primarily because of the large volume of sediments deposited in the Colorado River delta during the past 5 m.y. [14].

Death Valley (Figure 1) is a well-studied example of a rift basin where strike-slip deformation is occurring contemporaneously with crustal extension. Death Valley is a deep topographic basin that extends for about 200 $\mathrm{km}$ in north-northwest direction in southeastern California. Death Valley is a pull-apart basin [18] formed at a right stepping bend in the right-lateral Death Valley fault system. The geophysical data indicate that the valley fill consisting of alluvium, lacustrine, and evaporite deposits is about $3 \mathrm{~km}$ thick [19], and when combined with geodetic data from the Black Mountains, indicate a vertical separation of approximately $5 \mathrm{~km}$ across the Black Mountains fault zone at Badwater.

\section{DATA}

\subsection{Receiver Functions}

A receiver function is the seismic response of the earth beneath a seismic station to an incoming $P$-wave. In particular, a receiver function maps $P$-to- $S$ converted energy that occurs from impedance contrasts (i.e., layers of different velocity and density) in the earth. First-order information about the crustal structure can be derived from the radial receiver function, which is dominated by $P$-to- $S$ converted energy from a series of velocity discontinuities in the crust and upper mantle [20]. Thus, receiver functions can provide very good point measurements of crustal thickness under a broadband station. Receiver functions can be used to determine crustal thickness and $V_{p} / V_{s}$ ratios, and to determine the lateral variation of the Moho depth [21].

We employ the receiver function technique using the iterative deconvolution method of [22] and the stacking approach described in [22]. In receiver function estimation, the foundation of the iterative deconvolution approach is least squares minimization of the difference between the observed horizontal component seismogram and predicted signal generated by convolution of an iterative updated spike train with the vertical component seismogram [22]. We compute receiver functions using the iterative time deconvolution with Gaussian width (Ga) factors of $2.5,1.75$, and 1 which is equivalent to applying low pass filters with cutoff frequencies of 1.2, 0.9 , and $0.5 \mathrm{~Hz}$, respectively.

We collected waveforms of teleseismic earthquakes with $\mathrm{M}>5.5$ from 27 broadband seismograph stations (shown in Figure 2) for the Salton Trough and 13 broadband seismograph stations (shown in Figure 3) for Death Valley, that recorded from 2000 to 2009. These data were downloaded directly from the Incorporated Research Institutes for Seismology (IRIS) Data Management Center using the Standing Order of Data, which allowed for automated rotation of the horizontal components to radial and transverse directions. From the waveform data, we computed the radial and transverse receiver functions using the iterative deconvolution method, keeping data with an $80 \%$ or greater fit. We also manually inspected each radial receiver function to ensure quality. We then stacked the radial receiver functions using the approach of [21].

The time separation $t$ between $P s$ and $P$ can be used to estimate crustal thickness $(H)$, given the average crustal velocity:

$$
H=\frac{t_{P s}}{\sqrt{\frac{1}{V_{s}^{2}}-p^{2}}-\sqrt{\frac{1}{V_{p}^{2}}-p^{2}}}
$$

where $p$ is the ray parameter of the incident wave. One problem is the trade-off between the thickness and crustal velocities, since $t_{P S}$ represents the differential travel time of $S$ with respect to $P$ wave in the crust. The dependence of $(H)$ on $V_{p}$ is not as strong as on $V_{s}$ or more precisely on the $V_{p} / V_{s}$ ratio $(K)$, which means the uncertainty of $(H)$ is $<0.5 \mathrm{~km}$ for a $0.1 \mathrm{~km} / \mathrm{s}$ uncertainty 


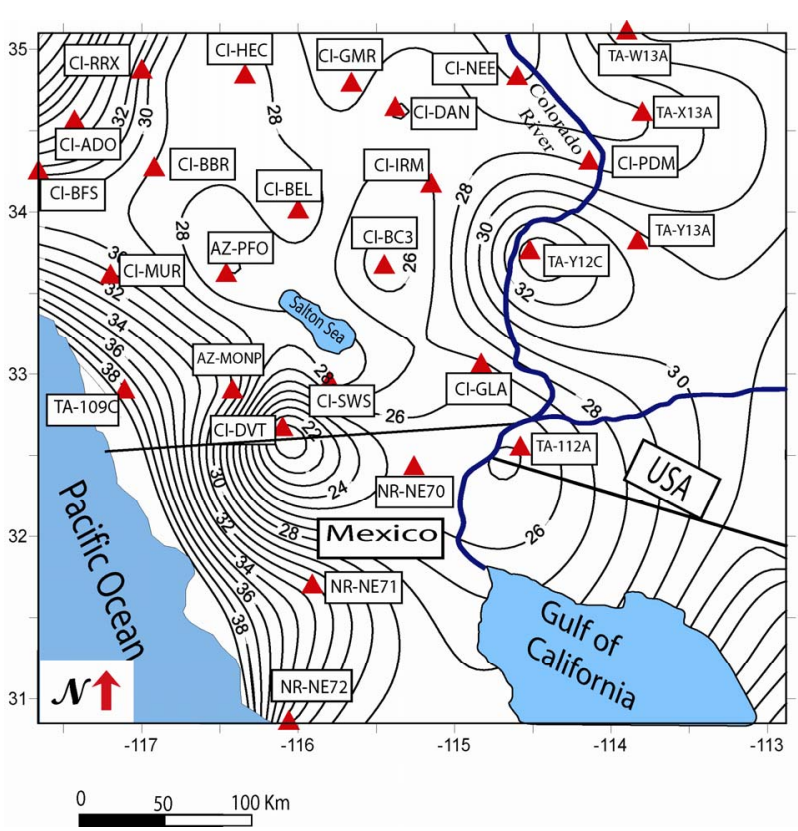

Figure 2. Contour map of the Moho depth $(\mathrm{km})$ in the Salton Trough based on receiver function data. Data were collected from 27 stations (shown as triangles). Stations codes are shown inside small squares beside each station.

in $V_{p}$; while a 0.1 change in $(K)$ can lead to about $4 \mathrm{~km}$ change in the crustal thickness [21].

\subsection{Gravity Data}

We obtained gravity data from the University of Texas at El Paso (UTEP)-Pan American Center of Earth and Environmental Studies (PACES) (http://www.research.utep.edu/paces) that is currently hosted at the CYBER-ShARE Center of Excellence at UTEP. The gravity data were merged from a variety of surveys and cover the US and the border region. The average error for this data set ranges from 0.05 to $2 \mathrm{mGal}$ (Al-Douri, personal communication, 2010). Terrain corrections were calculated by [23] of the US Geological Survey (USGS) using a digital elevation model and a technique based on the approach of [24]. A Bouguer gravity correction was made using $2670 \mathrm{~kg} / \mathrm{m}^{3}$ as the reduction density.

We used 40,784 Bouguer gravity points to create the Bouguer gravity anomaly map of the Salton Trough (Figure 4), and used 7930 Bouguer gravity points to create the Bouguer gravity anomaly map of Death Valley (Figure 5).

\section{CRUSTAL MODELS}

We use receiver function and gravity data to create 2.5D crustal scale models for the Salton Trough and Death Valley. According to the receiver functions analy-

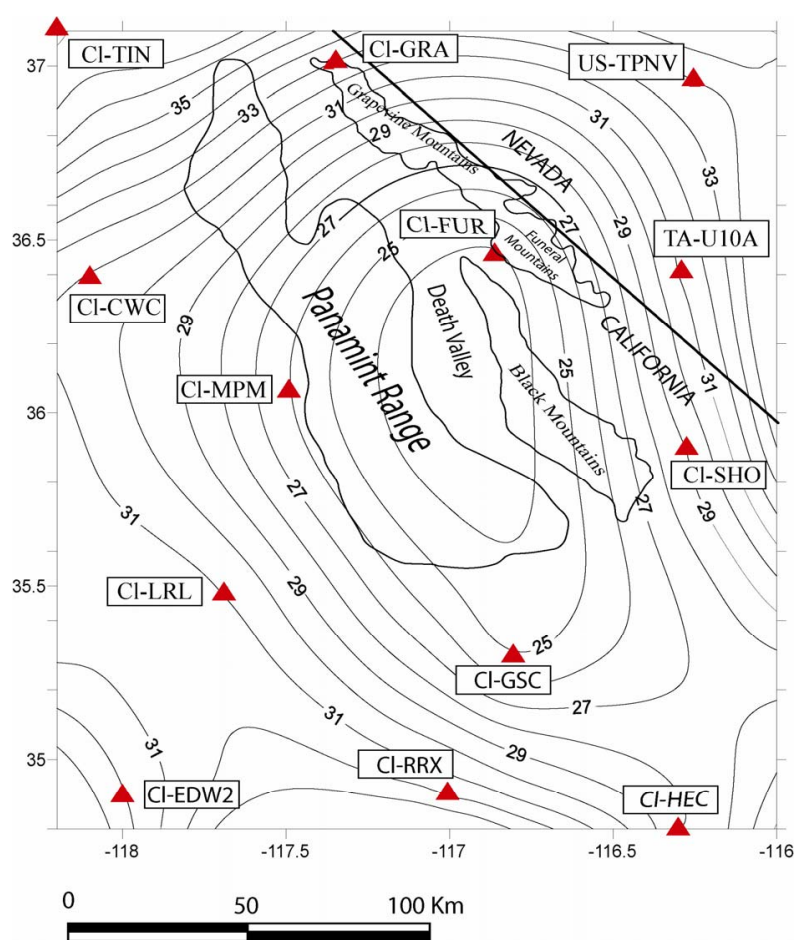

Figure 3. Contour map of the Moho depth $(\mathrm{km})$ in Death Valley based on receiver function data. Data were collected from 13 stations (shown as triangles). Stations codes are shown inside small squares beside each station.

sis [25], the Moho depth varies significantly between the western edge of Peninsular Ranges at $38 \mathrm{~km}$ and the western edge of the Salton Trough at $22 \mathrm{~km}$. The presence of a steeply dipping Moho beneath the eastern Peninsular Ranges strongly suggests the isostatic compensation is through lateral variation in crustal or upper mantle density rather than through an Airy root [26].

Bouguer gravity anomalies of the Salton Trough indicate that the most important gravity anomalies trend in the NW and NE directions. Large amplitude gravity anomalies are observed over exposed crystalline rocks and over Mesozoic and Tertiary sedimentary rocks.

Crustal model of the Salton Trough (Figure 6) is $\sim 470 \mathrm{~km}$ long and cross the central regions of the Salton Trough. The depth to the Moho, according to the receiver function, varies from $38 \mathrm{~km}$ under Peninsular Ranges to $25 \mathrm{~km}$ south of the Salton Sea, deepens to 32 $\mathrm{km}$ at the end point of the model (Moho depth of $22 \mathrm{~km}$ is located to the south of our model). Density for the upper crust varies from $2500 \mathrm{~kg} / \mathrm{m}^{3}$ to $2600 \mathrm{~kg} / \mathrm{m}^{3}$ and in the middle crust density is $2750 \mathrm{~kg} / \mathrm{m}^{3}$ increase to $2950 \mathrm{~kg} / \mathrm{m}^{3}$ for the lower crust. Lower crust density reflects gabbroic composition of the lower crust or oceanic crust which indicates a late stage of rifting.

We modeled a magmatic underplating (mixture of upper mantle and lower crust material) at a depth of $\sim 20$ 

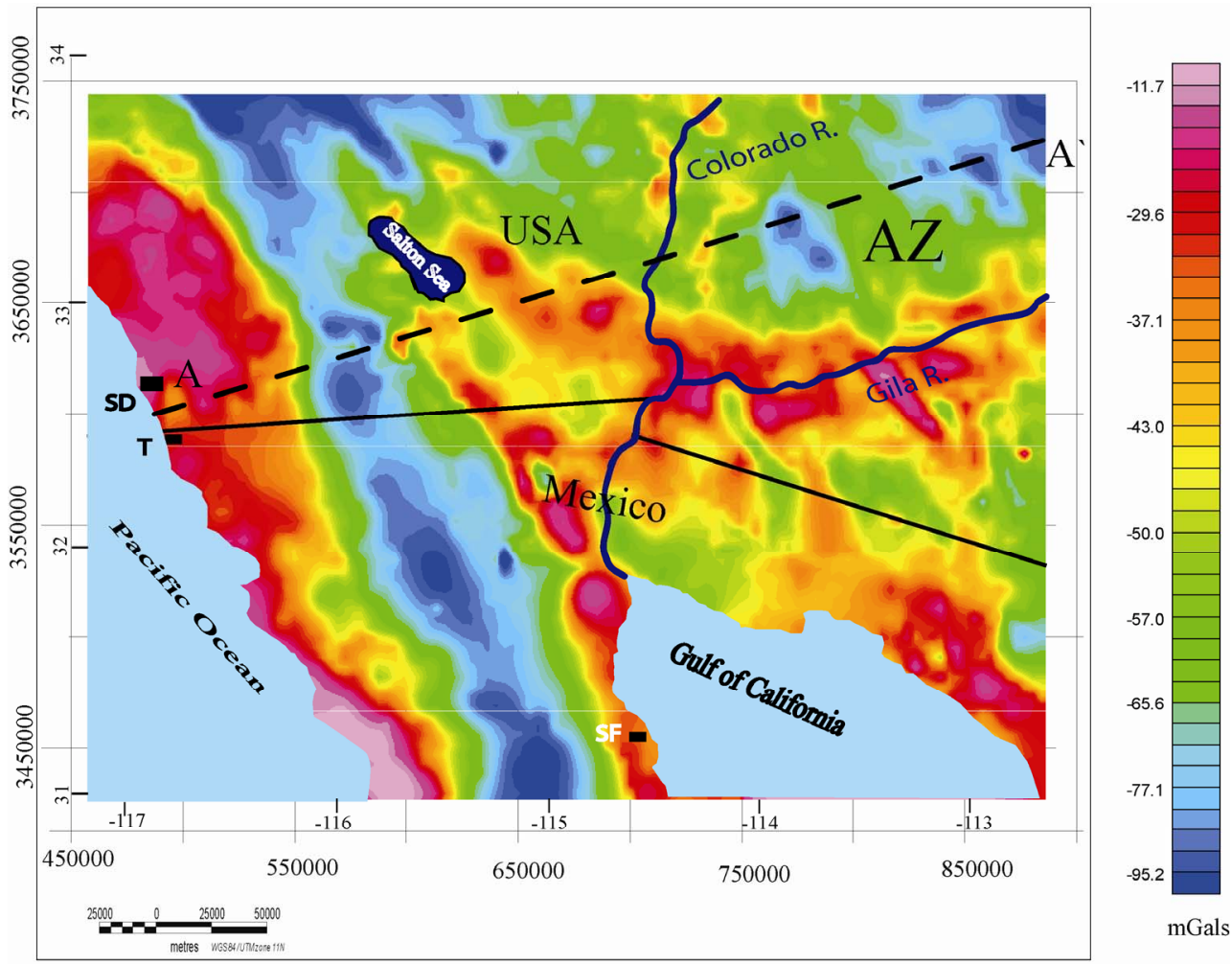

Figure 4. Bouguer gravity anomaly map of the Salton Trough. Dashed line A-A' shows the location of the crustal model of Figure 6. SD; San Diego, T; Tijuana, SF; San Felipe.

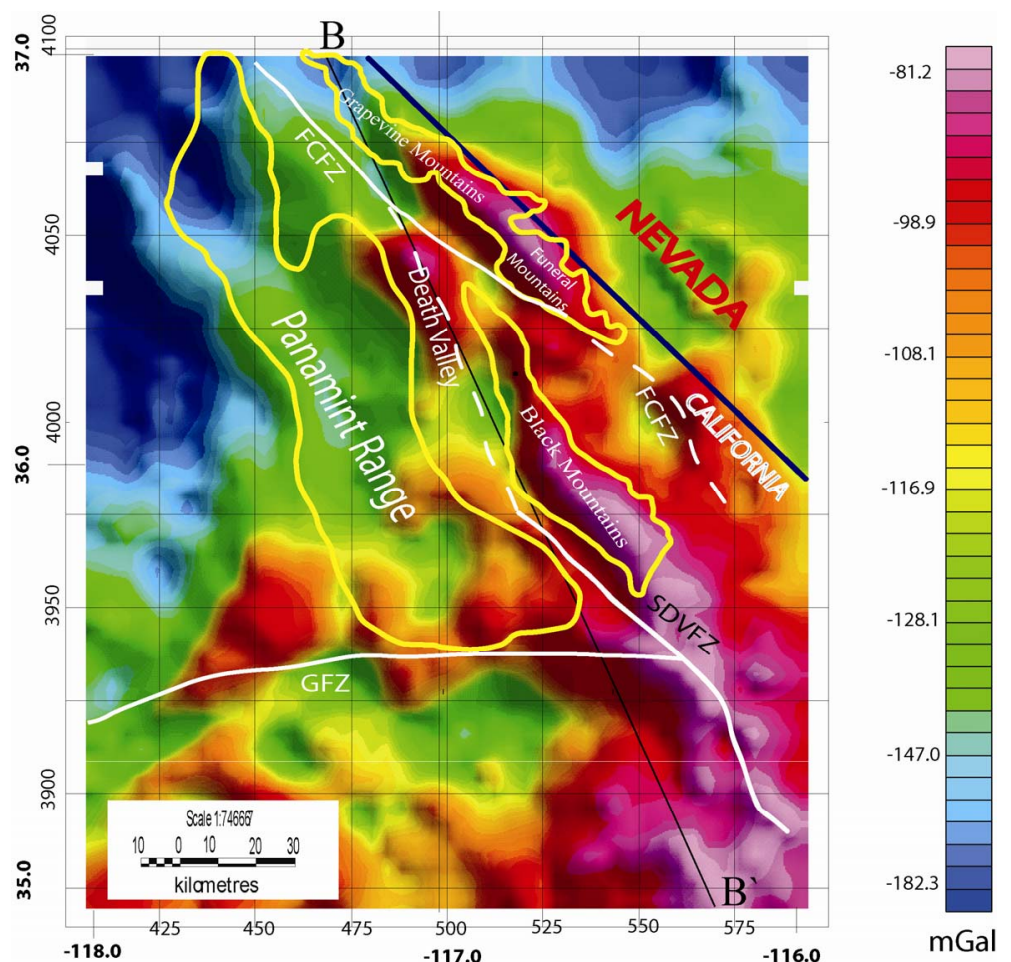

Figure 5. Bouguer gravity anomaly map of Death Valley. Dashed line B-B' shows the location of the crustal model of Figure 7. FCFZ; Furnace Creek fault zone, SDVFZ; Southern Death Valley Fault zone, GFZ; Garlock Fault Zone. 
A (Southwest)

A (Nomeast)
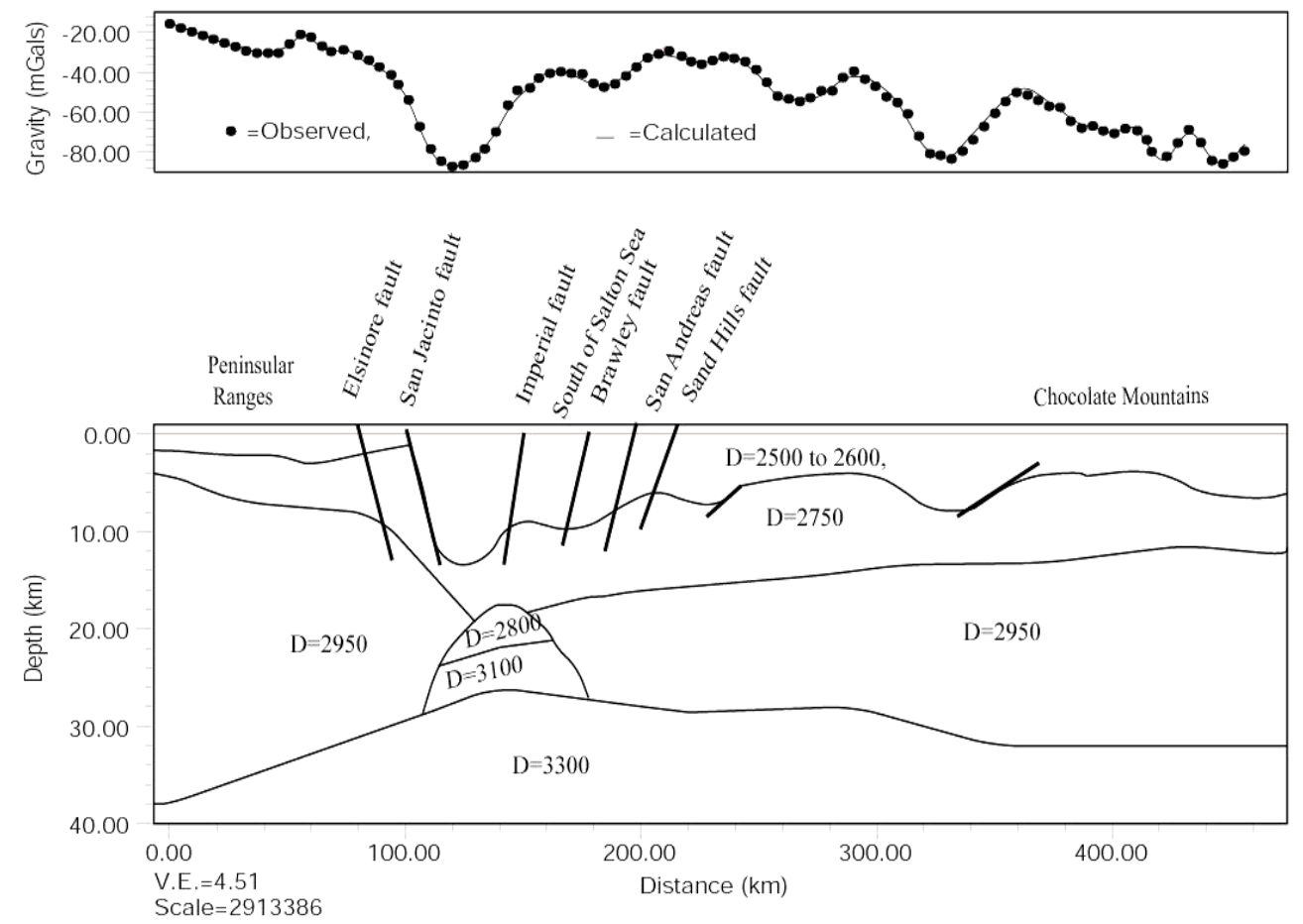

Figure 6. Interpretative model for profile A-A'. This model is about $\sim 470 \mathrm{~km}$ long, cross the central part of the Salton Trough.

$\mathrm{km}$ south of Salton Sea, reference [25] showed the same magmatic body in lower Gila River at a depth of $27 \mathrm{~km}$, which may suggests the magmatic body extend with greater depth to the southeast of the Salton Trough. Magmatic underplating has been suggested to be the cause of the uplift, melting, and recrystallization of the lower crustal rocks and to produce extension and basin sedimentation in the upper crust [14]. We infer magmatic underplating is an evidence for slip and activity transfer from one location to another which is consistent with $[14,27,28]$. The Salton Trough model shows variation in the thickness of the sediments and sedimentary basins, thickness of sediments and sedimentary basins ranges from $6-10 \mathrm{~km}$.

In Death Valley the Moho appears to have a dome shape, with the Moho depth in central Death Valley estimated to be $24 \mathrm{~km}$ and deepening to approximately 31 $\mathrm{km}$ outside the valley [29]. The Moho is shallow and may form a flat-topped dome centered beneath the southern and central Death Valley basins. The flat topped dome peaks beneath the area of active upper crustal extension and is suggested, here, to be primarily the product of magmatic activity in the lower crust and upper mantle.

Bouguer gravity anomalies of Death Valley show decrease of Bouguer gravity values in the Black Mountains to the west and north of the Black Mountains. Low gravity anomalies are likely caused by metasedimentary and granitic rocks or by thicker crust or both.

Figure 7 shows the Death Valley crustal model that runs through the central Death Valley Basin. Moho depths are consistent with the receiver function data which suggest the Moho is shallow and, possibly, domed or flat topped in shape in central Death Valley basin $(\sim 24 \mathrm{~km})$; the flat topped shape beneath the area of active upper crust extension is suggested to be primarily the product of magmatic activity in the lower crust and upper mantle [30]. Thickness of sediment and sedimentary basins ranges from $3-5 \mathrm{~km}$.

\section{RIFTING STYLE AND RIFTING FORCES}

An important structural classification of rifts is by width [31], with narrow rifts thought to form as necking instabilities [32] where extension rates outpace thermal diffusion and wide rifts are thought to require a mechanism, such as lower-crustal flow in high heat-flow settings, to inhibit localization of deformation [33]. The initial width of an individual rift is a direct function of thickness of the brittle upper crust [34]. Narrow rifts have a characteristic width of $30-40 \mathrm{~km}$; the width of wide rifts can reach a $1000 \mathrm{~km}$. Narrow rift width is less than $200 \mathrm{~km}$ while wide rift width is greater than $200 \mathrm{~km}$ [4].

Observations of the magmatism that results from rift- 
$\mathrm{B}(\mathrm{N}-\mathrm{NW})$

B'(S-SE)

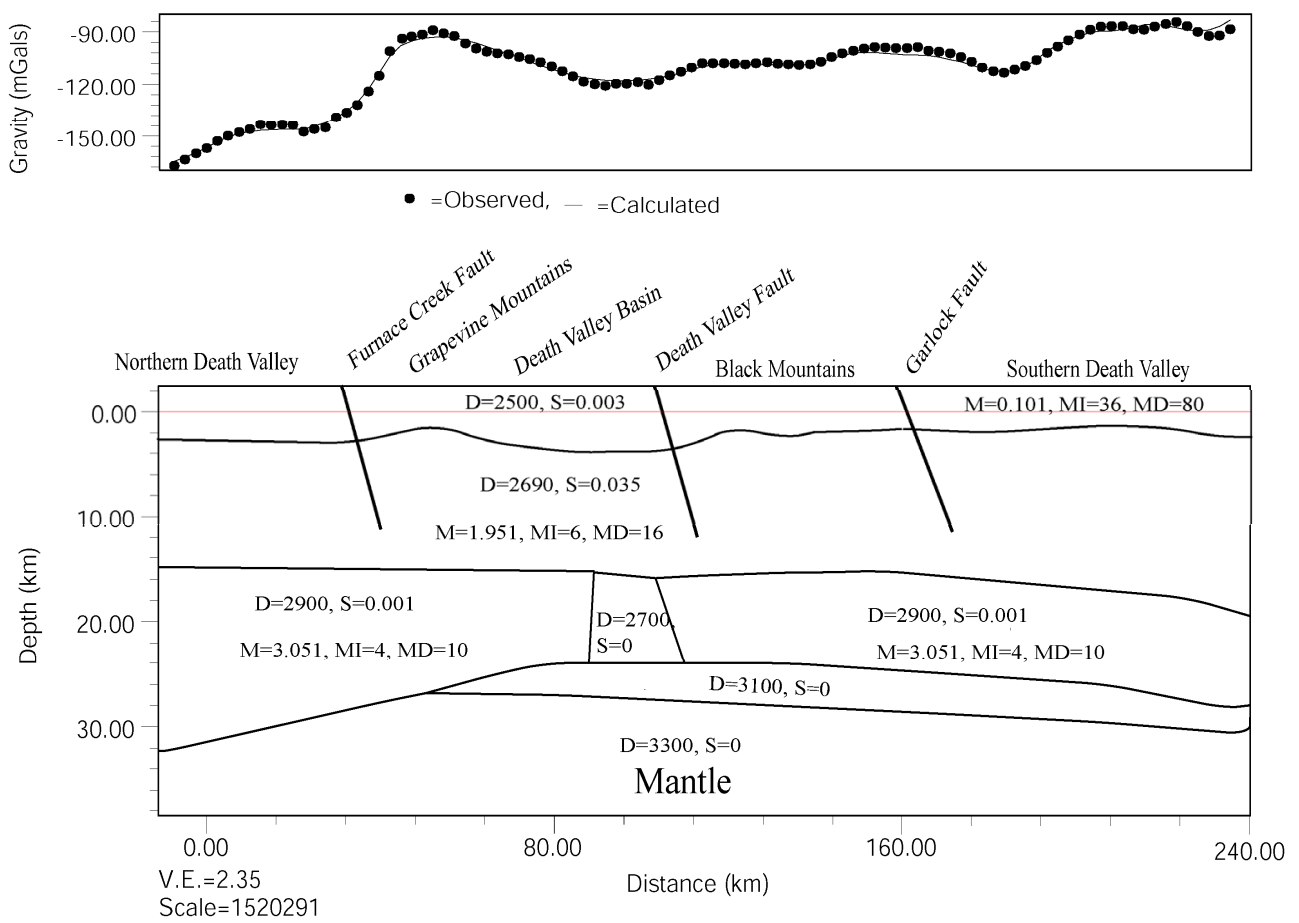

Figure 7. Interpretative model for profile B-B'. The model is $\sim 240 \mathrm{~km}$ long, and passes through the Death Valley and Black Mountains anomalies.

ing range from volcanic margins with two to three times the magmatism predicted from melting models to nonvolcanic margins with almost no rift or post-rift magma tism. Such variations in magmatic activity are commonly attributed to variations in mantle temperature. Over short lateral distances, large differences in rifting style and magmatism from wide rifting with minor synchronous magmatism to narrow rifting in magmatically robust segments [4].

The thermal regime drives rifting in Salton Trough and Death Valley. We modeled a magmatic body to the southwest of Salton Sea at a depth of $20 \mathrm{~km}$ that extends for about $70 \mathrm{~km}$ in SW-NE direction (Figure 6). The Death Valley model includes a magmatic body that underlies the central basin of Death Valley at depth of $24-25$ $\mathrm{km}$ and extends for at least $160 \mathrm{~km}$ in NW-SE direction.

The rapid flux of sediments to rift basins exerts a strong influence on deformation style, crustal rheology, syn-rift magmatism, and rift architecture $[4,35,36]$. We expect sedimentation rate and flux contribute to the rifting process and considered to be a rifting driving force in the Salton Trough but not Death Valley, according to our models sedimentary basins are $6-10 \mathrm{~km}$ thick in Salton Trough and $3-5 \mathrm{~km}$ in Death Valley. Summary of the similar and different geological features between the Salton Trough and Death Valley pull apart basins in
Table 1.

\section{DISCUSSION}

We created crustal scale models for the Salton Trough and Death Valley by incorporating receiver function and gravity data.

Receiver function analysis revealed a dome shaped Moho in Death Valley that peaks beneath the area of active upper crust extension and is suggested to be primarily the product of magmatic activity in the lower crust and upper mantle. In the Salton Trough there is significant variation in Moho depth between the Peninsular Ranges and west margin of Salton Trough. The steeply dipping Moho is a regional feature beneath the eastern Peninsular Ranges, and that the compensation is through lateral variation in crustal or upper mantle density rather than through an Airy root [26].

According the crustal models major faults (Elsinore, San Jacinto, San Andreas, Imperial faults) in the Salton Trough (Figure 6) extend for more than $12 \mathrm{~km}$. While major faults (Furnace Creek, Garlock, Death Valley faults) in Death Valley (Figure 7) extends to about 12 $\mathrm{km}$. Our models suggest that the extension is intense in the weakest, thinnest area of the lithosphere which is consistent with [37]. We modeled magmatic underplating as 
Table 1. Summary of comparison between the Salton Trough and Death Valley.

\begin{tabular}{|c|c|c|}
\hline Geologic Feature & Salton Trough & Death Valley \\
\hline Length & $\sim 250 \mathrm{~km}$ & $\sim 200 \mathrm{~km}$ \\
\hline Width & $\begin{array}{l}\text { Narrow rift, but wider than Death Valley the width of Salton } \\
\text { Trough is } 20 \mathrm{~km} \text { in the north increase to } 60 \mathrm{~km} \text { to the south, } \\
\text { especially Southern Salton Sea area. }\end{array}$ & Narrow ( 8 to $25 \mathrm{~km}$ ) depression. \\
\hline -Rifting Stage & $\begin{array}{l}\text { Well developed } \\
\text { Moving toward sea floor spreading }\end{array}$ & $\begin{array}{l}\text { In its initial stage of rifting mostly will } \\
\text { not develop to further stage no evi- } \\
\text { dence for extensional activity. }\end{array}$ \\
\hline -Densities & High crustal density (Gabbroic) & Less than the Slaton Trough. \\
\hline -Depth to the Moho & $\begin{array}{l}22 \mathrm{~km} \text { to the southwest of the Salton Sea on the US-Mexico } \\
\text { border, and deepens to } 32 \mathrm{~km} \text { to the west and east }\end{array}$ & $\begin{array}{l}24 \mathrm{~km} \text { central Death Valley and deepens } \\
\text { to } 32 \mathrm{~km} \text { (dome in shape). }\end{array}$ \\
\hline -Sediments and metasedimenatry & $\begin{array}{l}\text { The Salton Trough contains about } 10 \mathrm{~km} \text { of sediment deposited } \\
\text { from the ancestral Colorado River The present day Salton } \\
\text { Trough differs from analogous structures to the south in the } \\
\text { Gulf of California primarily because of large amounts of } \\
\text { sediment deposited through the growth of the Colorado River } \\
\text { delta. This sedimentation may play a strong role in reducing } \\
\text { the apparent structural relief in the Salton Trough. }\end{array}$ & $\begin{array}{l}\text { The sedimentary basins in Death Valley } \\
\text { as isolated, discontinuous depressions, } \\
\text { deeper than } 1 \mathrm{~km} \text { and often more than } 3 \\
\mathrm{~km} \text {; these basins have steep margins } \\
\text { often around their entire perimeter, and } \\
\text { typically horizontal dimensions of } 5-15 \\
\mathrm{~km} \text { [33]. }\end{array}$ \\
\hline -Major Faults & Extends for more than $12 \mathrm{~km}$ & Extends for about $12 \mathrm{~km}$ \\
\hline -Rifting Driving Force & Combination of thermal and sedimentation & Thermal \\
\hline
\end{tabular}

a magmatic body which is inferred to be a mixture of lower crust and upper mantle material, to fit this body to our models we presumed the density of this body to be $3100 \mathrm{~kg} / \mathrm{m}^{3}$, this deeper magma extends for at least 160 $\mathrm{km}$ in NW-SE direction in Death Valley [29] and extends for $70 \mathrm{~km}$ in SW-NE direction in Salton Trough.

The sedimentary basins in Death Valley have been described [38] as isolated, discontinuous depressions, deeper than $1 \mathrm{~km}$ and often more than $3 \mathrm{~km}$; these basins have steep margins often around their entire perimeter, and typically horizontal dimensions of $5-15 \mathrm{~km}$. The Salton Trough contains about $10 \mathrm{~km}$ of sediments deposited as alluvial debris, thin marine beds, and deposits from the ancestral Colorado River [17]. Sedimentation rate and sedimentary and metasedimantary rocks thickness, and the difference in density between the lower and upper most crust may reflect the role of sedimentation as a rifting force in the Salton Trough. The Colorado River has delivered a large volume of sediments to the Salton Trough over the past 5 - 6 m.y., supplying felsic material that is quickly buried and metamorphosed to form a new generation of crust transferred from the craton interior [39]. The seafloor expression is masked by sediment thickness [4]; thick sediments gives the impression of wider rift, for example Salton trough is $20 \mathrm{~km}$ wide in its northern part and $60 \mathrm{~km}$ wide in its southern area [40], and cover with thick sediments from sedimentation flux from Colorado river. Four main processes affect continental extension: 1) thinning of the crust and lithosphere 2) diffusion of heat 3 ) flow of lower crust, and 4) sedi- mentation [36,37]. Sediments are one of the main recorders of tectonic events, and also affect the way compression or extension proceeds. The weight of sediments reduce the difference in crustal buoyancy forces caused by local crustal thinning allowing the rift to extend more easily in a narrow rift mode [36]. Large inputs of sediments may have a thermal blanketing effect [4] where the continental crust is heated by being depressed to a higher temperature regime thereby weakening it. Presumably, the thermal blanket would promote narrow rifting in the areas of thickest sediments. Our models suggest that the extension is intense in the weakest, thinnest area of the lithosphere which is consistent with [37].

\section{CONCLUSIONS}

Crustal scale models, and comparative studies help better understand the process that drives continental rifting. According to receiver function analysis the Moho is concave upwards in both areas. Although the two rifts are classified as narrow rifts based on their width, there are significant differences, especially in the rifting driving force. Crustal models show a magmatic body underlies the central Death Valley basin, and a magmatic body to the southwest of Salton Sea. Both magmatic bodies play a significant role in heating, stretching, and extending the crust. Sedimentary flux, and sedimentation rate and large density variation between upper and lower crust provide an evidence for sedimentation force in the 
Salton Trough as a rifting driving force which is absent in Death Valley. The Salton Trough is wider than Death Valley and in its seafloor stage. We anticipate both rifts are active, activity concentrated in the central basin of Death Valley, and to the south and southwest of Salton Sea in the Salton Trough, where the Moho is shallow and geothermal activity is expected.

\section{ACKNOWLEDGEMENTS}

We would like to thank Dr. Terry Pavlis, Dr. William Cornell and Dr. Vladik Kreinovich for helpful discussion. We would like also to thank Dr. Raed Al-Douri, Carlos Montana for the technical support. We would like also to thank anonymous reviewer for his constructive comments. The work was partially supported by NSF grant number HRD-0734825.

\section{REFERENCES}

[1] Adams, D. (1996) Integrated geophysical studies of continental rifts in west Texas and New Mexico. Ph. D. Dissertation, University of Texas at El Paso, El Paso.

[2] Mickus, K., Stern, R., Keller, G. and Anthony, E. (2009) Potential field evidence for a volcanic rifted marging along the Texas Gulf Coast. Geology, 37, 387-390. doi:10.1130/G25465A.1

[3] Keller, R., Khan, A., Morgan, P., Wendland, R., Baldridge, W., Olson, K., Prodhel C. and Braile L. (1991) A comparative study of the Rio Grande and Kenya rifts. Tectonophysics, 197, 355-371.

doi:10.1016/0040-1951(91)90050-3

[4] Lizarralde, D., Axen, G., Brown, H., Fletcher, J., Gonzalez-Fernandez, A., Holbrook, W., Kent, G., Paramo, P., Sutherland, F. and Umhoefer, P. (2007) Variation in styles of rifting in the Gulf of California. Nature, 448, 466-469. doi:10.1038/nature06035

[5] Buck, W. (1988) Flexural rotation of normal faults. Tectonics, 7, 959-973. doi:10.1029/TC007i005p00959

[6] Wernicke, B., Axen, G. and Snow, J. (1989) Basin and Range extension tectonics at the latitude of Las Vegas. Nevada, Geological Society of America Bulletin, 11, 1738-1757.

[7] Keller, G., Morgan, P. and Seager, W. (1990) Crustal structure, gravity anomalies, and heat flow in the southern Rio Grande rift and their relationship to extensional tectonics. Tectonophysics, 174, 21-37. doi:10.1016/0040-1951(90)90382-I

[8] Lachenbruch, A. and Morgan, P. (1990) Continental extension, magmatism and elevation: Formal relations and rules of thumb. Tectonophysics, 174, 39-62. doi:10.1016/0040-1951(90)90383-J

[9] Lense, C., Deverchere, J., Sankov, V., Lukhnev, A., Miroshnichenko, A. and Levi, K. (1998) Crustal deformation in the Baikal rift from GPS measurements. Geophysical Research Letters, 25, 4003-4006. doi:10.1029/1998GL900067

[10] Buck, W., Lavier, L. and Babeyko, A. (2003) A numerical model of lithospheric extension producing faultbounded basins and ranges. International Geology Review, 45, 712-723.
[11] Dueker, K., Yuan, H. and Zurek, B. (2001) Thick-structured proterozoic lithosphere of the rocky mountain region. GSA Today, 11, 4-9. doi:10.1130/1052-5173(2001)011<0004:TSPLOT $>2.0 . \mathrm{C}$ $\underline{\mathrm{O} ; 2}$

[12] Wilson, D., Leon, J., Aster, R., Ni, J., Schlue, J., Grand, S., Semken, S., Baldridge, S. and Gao, W. (2002) Broadband seismic background noise at temporary seismic stations observed on a regional scale in the southwestern United States. Bulletin of Seismological Society of America, 92, 3335-3341. doi:10.1785/0120010234

[13] Parsons, T. and McCarthy, J. (1996) Crustal and upper mantle velocity structure of the Salton Trough southeast California. Tectonics, 15, 456-471. doi:10.1029/95TC02616

[14] Parsons, T., McCarthy, J. and Thompson, G. (2001) Very different crustal response to extreme extension in the southern basin and range and Colorado Plateau transition. In: Erskine. M., Faulds, J., Bartley, J. and Rowley, G.B., Eds., American Association of Petroleum Geologists Pacific Section Guidebook, 291-304.

[15] Fuis, G., Mooney, W., Healey, J., McMechan, G. and Lutter W. (1984) A seismic refraction survey of the Imperial Valley region, California. Journal of Geophysical Research, 89, 1165-1189. doi:10.1029/JB089iB02p01165

[16] Larsen, S. and Reilinger, R. (1991) Age constraints for the present fault configuration in the Imperial Valley, California: Evidence for northwestward propagation of the Gulf of California rift system. Journal of Geophysical Research, 96, 10339-10446. doi:10.1029/91JB00618

[17] Crowell, J. (1989) Sedimentation and tectonics along the San Andreas transform belt. In: Sylvester, A. and Crowell, J., Eds., Sedimentation and Tectonics of North America Belt, Field Trips for the 28th International Geological Congress, Washington DC, American Geophysical Union, 32-35

[18] Burchfiel, B. and Stewart, J. (1966) Pull-apart origin of the central segment of the Death Valley, California. Geological Society of America Bulletin, 77, 439-442. doi:10.1130/0016-7606(1966)77[439:POOTCS]2.0.CO;2

[19] Serpa, L., deVoogd, B., Wright, L., Willemin J., Oliver, Hauser, E. and Troxel, B. (1988) Structure of the central Death Valley pull apart basin and vicinity from the COCORP models in the southern Great Basin. Geological Society of America Bulletin, 100, 1437-1450. doi:10.1130/0016-7606(1988)100<1437:SOTCDV $>2.3$. $\mathrm{CO} ; 2$

[20] Ammon, C., Randall, G. and Zandt, G. (1990) On the nonuniqueness of receiver function inversions. Journal of Geophysical Research, 95, 15303-15318, doi:10.1029/JB095iB10p15303

[21] Zhu, L. and Kanamori, H. (2000) Moho depth variation in southern California from teleseimic receiver functions. Journal of Geophysical Research, 105, 2969-2980. doi: 10.1029/1999JB900322

[22] Ligorria, J. and Ammon, C. (1999) Iterative deconvolution and receiver function estimation. Bulletin of Seismological Society of America, 89, 1395-1400.

[23] Webring, M. (1982) MINC, a gridding program based on minimum curvature. US Geological Survey Open-File Report, 43, 81-1224. 
[24] Plouff, D. (1977) Preliminary documentation for a FORTRAN program to compute gravity terrain corrections based on topography digitized on a geographic grid. US Geological Survey Open File Report, 45, 77-535.

[25] Hussein, M. (2007) Integrated and comparative geophysical studies of crustal structure of pull-apart basins: The Salton Trough and Death Valley, California regions. Ph.D. Dissertation, University of Texas at El Paso, El Paso.

[26] Lewis, J., Day, S., Magistrale, H., Ealins, J. and Vernon, F. (2000) Regional crustal variations off the Peninsular Ranges, Southern California. Geology, 28, 303-306. doi:10.1130/0091-7613(2000)28<303:RCTVOT $>2.0$.CO ;2

[27] Lachenbruch, A., Sass, J. and. Galanis, S.Jr. (1985) Heat flow in southernmost California and the region of the Salton Trough. Journal of Geophysical Research, 90, 6709-6736. doi:10.1029/JB090iB08p06709

[28] Lonsdale, P. (1989) Geological and tectonic history of the Gulf of California. In: Wintere, D., Husson, M. and R. Decker, R., Eds., The Eastern Pacific Ocean and Hawaii, Geological Society of America, N, 499-521.

[29] Hussein, M., Serpa, L., Velasco, A. and Diane, D. (Unpublished) Imaging the deep structure of the Central Death Valley basin using receiver function, gravity, and magnetic data. International Journal of Geosciences.

[30] Serpa, L. (1990) Structural styles across an extensional orogen; results from the COCORP Mojave and Death Valley seismic transects. In: Wernicke, B.P., Ed., Basin and Range Extensional Tectonics near the Latitude of Las Vegas, Nevada, Geological Society of America Memoir Boulder, Colorado, 176, 335-344

[31] Hopper, J. and Buck, W. (1996) The effect of lower crustal flow on continental extension and passive margin formation. Journal of Geophysical Research, 101, 21175 20194. doi:10.1029/96JB01644

[32] Braun, J. and Beaumont, C. (1987) Styles of continental rifting from dynamical models of lithospheric extension. Mem. Canadian Society Petroleum Geologists, 12, 241258.

[33] Buck, W., Lavier, L. and Poliakov, A. (1999) How to make a rift wide. Philosophical Transactions of the Royal Society of London, 357, 671-693.

[34] Brun, J. (1999) Narrow rifts versus wide rifts: Inferences for the mechanics of rifting from laboratory experiments, Philosophical Transactions of the Royal Society of London Ser. A-Mathematical Physical and Engineering Sciences, 357, 695-712.

[35] Gonzalez-Fernandez, A., Daaobeitia, J., Delgado-Argote L., Michaud, F., Cordoba, D. and Bartolome, R. (2005) Mode of extension and rifting history of upper Tiburon and upper Delfin basins, northern Gulf of California. Journal of Geophysical Research, 110, B01313

[36] Bialas, R. and Buck, W. (2009) How sediment promotes narrow rifting: Application to the Gulf of California, Tectonics, 28, TC4014.

[37] Buck, W. (1991) Modes of continental lithospheric extension. Journal of Geophysical Research, 96, 2016120178.

[38] Blakely, R., Jachens, R., Calzia, J. and Langenheim, V. (1999) Cenozoic basins of the Death Valley extended terrane as reflected in regional-scale gravity anomalies. In: Wright, L.A. and Troxel, B.W., Eds., Cenozoic Basins of the Death Valley Region, Geological Society of America Special Paper, Boulder, Colorado, 333, 1-16.

[39] Dorsey, R. (2010) Sedimentation and crustal recycling along an active oblique-rift margin: Salton Trough and northern Gulf of California. Geological Society of America, 38, 443-446.

[40] Muffler, L. and Doe, B. (1968) Composition and mean age of detritus of the Colorado River delta in the Salton Trough, southeastern California. Journal of Sedimentary Petrology, 38, 384-399. 